\title{
Fulvic acid isolation and characterisation from water of a Ramsar Lake Mansar, J\&K, India
}

\author{
Arti Sharma ${ }^{1} \cdot$ Ritika Anthal $^{1}[$
}

Received: 9 June 2020 / Accepted: 10 November 2021 / Published online: 21 November 2021

(C) The Author(s) 2021

\begin{abstract}
The present study was undertaken with the aim to understand the chemical properties of aquatic fulvic acid in a clear water Lake Mansar. Along with that, the physical and chemical environment of the lake was also analysed. Fulvic acid was isolated from the water of Lake Mansar following IHSS recommended methodology and was subjected to characterisation, viz. elemental analysis, H-NMR and FTIR spectroscopy. The yield of fulvic acid from water of Lake Mansar was $0.22 \mathrm{mg} / \mathrm{L}$ that was far less than coloured aquatic systems. Elemental analysis revealed per cent carbon, hydrogen, nitrogen and oxygen content to be 53.6\%, 5.04\%, 6.3\% and 35.06\%, respectively. H-NMR and FTIR spectra revealed the presence of various functional groups like aliphatic, hydroxyl, amide, quinones, ketones, carbonyl, cellulose, etc. Based on the present studies, it was concluded that the origin of humic material in Lake Mansar is mostly from algae and non-vascular plants that have undergone less degree of humification.
\end{abstract}

Keywords Fulvic acid · Mansar $\cdot$ Water $\cdot$ Organic matter $\cdot$ Spectroscopy $\cdot$ Algae

\section{Introduction}

Aquatic ecosystems provide a variety of services to varied forms of life on earth, but their stability and sustainability in turn are a consequence of the complex interplay of their various components. Among these, dissolved organic matter (DOM) is quantitatively a minor portion but is important being involved in various biochemical and geochemical processes. The important constituents of DOM are humic substances, the refractory high molecular weight compounds produced by partial degradation and recombination of complex biomolecules. Humic substances lack the specific chemical and physical properties possessed by well-defined groups of organic compounds and can be differentiated from the non-humic substances that include the known groups of organic compounds like amino acids, sugars, fats and organic acids (Boggs et al. 1985; Thurman 1985; McKnight and Aiken 1998).

According to the International Humic Substance Society (IHSS), "Humic substances are complex and heterogenous

Ritika Anthal

ritika.anthal123@gmail.com

1 Department of Zoology, University of Jammu, Jammu, India mixtures of polydispersed materials formed by biochemical and chemical reactions during decay and transformation of plant and microbial remains (a process called humification)".

Constituting about $50-75 \%$ of dissolved organic carbon (DOC) in water (Robards et al. 1994; Hertkorn et al. 2002), these compounds play an important role in carbon and nitrogen cycles by trapping these into relatively inert compounds preventing their complete mineralisation and recycling (Szalay 1964; Manskaya and Drozdova 1968).

Humic substances can be differentiated into three components-humic acid, fulvic acid and humins on the basis of their molecular weight, solubility, elemental composition and functional groups. Humic acid is the high molecular weight fraction that is soluble at higher $\mathrm{pH}$ values but precipitates at acidic $\mathrm{pH}$, while Fulvic acid is soluble in water under all $\mathrm{pH}$ values and has moderate molecular weight ranging from 600 to $5000 \mathrm{Da}$. Humins are not soluble in water at any pH value (IHSS 1985; Beckett et al. 1987; Muscolo et al. 2007).

These compounds have a great impact on the properties and functions of aquatic ecosystems that influence its abiotic environment and ultimately determine the biotic community inhabiting therein. In India, a lot of work has been done on soil humic substances and toxicological studies with heavy metals and notable contributions in this field have been made 
by Banerjee et al. (1979), Ghosal et al. (1991), Varadachari et al. (1997), Srivastava et al. (1998), Pandey et al. (1999), Mukhopadhyay and Sanyal (2004), Paul and Jayakumar (2010) and Kar et al. (2011). However, natural aquatic environments have not been explored to a large extent so far. Considering their importance, this study was undertaken to isolate and characterise fulvic acid, the low molecular weight component of humic substances from water of Lake Mansar, one of the oldest lakes in the Himalayas.

\section{Methodology}

\section{Study area}

The present study was undertaken at Lake Mansar (Fig. 1). Lake Mansar is a sub-tropical, clear water monomictic lake situated in lower Shiwaliks of the Jammu region. It is located at a distance of $64 \mathrm{kms}$ from Jammu city. It is sub-oval in shape having a circumference of $3.4 \mathrm{~km}$ and a maximum depth of $38.25 \mathrm{~m}$ with no surface channels flowing into it and is fed by freshwater through surface runoff and subterranaean springs (NIH 1997; Gul 2004).

Lake Mansar is rich in biodiversity and harbours large number of organisms. Considering this, Lake Mansar was given the status of a Ramsar site in 2005.

Lake Mansar was selected for the present study because it is a clear water lake. Most of the studies related to aquatic humic substances have been done on aquatic systems with high colour and DOC concentrations. Hence, this study would add to the knowledge of humic substances in clear water systems with low DOC.

\section{Isolation of fulvic acid}

The surface water was collected from littoral region of Lake Mansar. Isolation of fulvic acid was done followed the method of Aiken et al. (1985), recommended by IHSS and Lamar et al. (2014). $50 \mathrm{~L}$ of water was filtered through a $0.45 \mu \mathrm{m}$ filter membrane and passed through XAD-7HP microporous resin. It was eluated with $\mathrm{NaOH}$, and the eluate was acidified to $\mathrm{pH} 1$ to separate the fulvic acid from the humic acid fraction. The fulvic acid fraction was further purified by passing it through another column of XAD $-7 \mathrm{HP}$ and then cation exchange resin. The final fraction was freeze dried to get Fulvic acid.

The isolated fulvic acid fraction was then subjected to characterisation using the following techniques:

Proton nuclear magnetic resonance spectroscopy $\left(H^{1}\right.$ $N M R$ ) For H-NMR characterisation, $50 \mathrm{mg}$ of sample was dissolved in a mixture of $0.02 \mathrm{~mL}$ of $5 \mathrm{M} \mathrm{NaOD}$ (Sodium deutreroxide) and $0.4 \mathrm{~mL}$ of $\mathrm{D}_{2} \mathrm{O}$ (Deuterium oxide) and analysed in the NMR spectrophotometer to obtain the spectrum, and the chemical shifts assignments were referred to Wershaw (1985), Kawahigashi et al. (1996) and Fujitake et al. (2009).

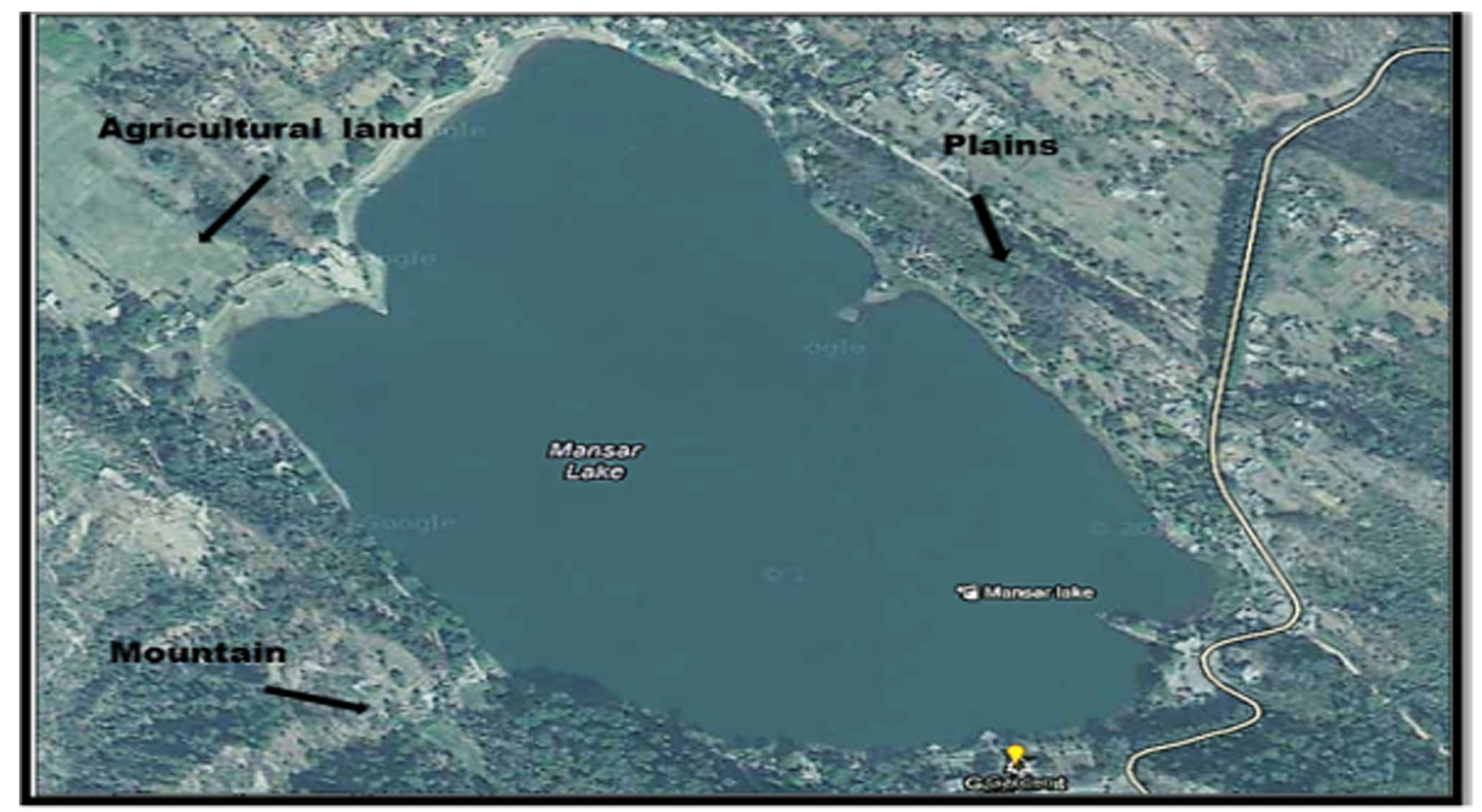

Fig. 1 Satellite image of Lake Mansar (Source Internet)

Springer 
Elemental analysis $\mathrm{CHN}$ Analyser was used for elemental analysis of humic substances.

Fourier transform infra-red spectroscopy (FTIR) For estimating the presence of various functional groups in the isolated fractions, $\mathrm{KBr}$ pellets containing $1 \%$ sample were analysed in the wavelength range of $500-4000 \mathrm{~cm}^{-1}$.

Along with these, seasonal analysis of various physical and chemical parameters of Lake Mansar water was also carried out following standard methodology (Adoni 1985; APHA 1985).

\section{Results and discussion}

Analysis of physical and chemical parameters of water of Lake Mansar provided an insight into the general conditions of Lake Mansar as depicted in Table 1. The value of secchi disc transparency was found to be more than half the depth of the study area that points towards the fact that Lake Mansar is a clear water lake. Moreover, lake water was found to be alkaline and DOM showed the mean value of $0.5075 \mathrm{mg} / \mathrm{L}$. The observed amount of DOM is comparable to other clear water systems (Fujitake et al. 2009). On the other hand, the concentration of DOM is usually very high

Table 1 Mean values of physical and chemical parameters of water of Lake Mansar during the study period (Summer 2015-Spring 2017)

\begin{tabular}{ll}
\hline Parameters & Mean values \\
\hline Air temperature $\left({ }^{\circ} \mathrm{C}\right)$ & 26.19 \\
Water temperature $\left({ }^{\circ} \mathrm{C}\right)$ & 24.66 \\
Depth $(\mathrm{cm})$ & 68 \\
Secchi transparency $(\mathrm{cm})$ & 52.75 \\
$\mathrm{pH}$ & 8.044 \\
Dissolved oxygen $(\mathrm{mg} / \mathrm{L})$ & 6.45 \\
Free carbon dioxide $(\mathrm{mg} / \mathrm{L})$ & 3.875 \\
Biological oxygen demand $(\mathrm{mg} / \mathrm{L})$ & 1.683 \\
Carbonates $(\mathrm{mg} / \mathrm{L})$ & 4.5 \\
Bicarbonates $(\mathrm{mg} / \mathrm{L})$ & 130.388 \\
Calcium $(\mathrm{mg} / \mathrm{L})$ & 22.508 \\
Magnesium $(\mathrm{mg} / \mathrm{L})$ & 19.903 \\
Chloride $(\mathrm{mg} / \mathrm{L})$ & 29.875 \\
Phosphate $(\mathrm{mg} / \mathrm{L})$ & 0.434 \\
Sulphate $(\mathrm{mg} / \mathrm{L})$ & 1.0375 \\
Nitrate $(\mathrm{mg} / \mathrm{L})$ & 0.4425 \\
Total dissolved solids $(\mathrm{mg} / \mathrm{L})$ & 208.125 \\
Dissolved organic matter $(\mathrm{mg} / \mathrm{L})$ & 0.5075 \\
\hline
\end{tabular}

in coloured water bodies with high amount of humic substances. Hence, Lake Mansar can be categorised as a clear water lake on the basis of its DOM content.

\section{Yield of fulvic acid}

The yield of Fulvic acid from the selected water body was $0.22 \mathrm{mg} / \mathrm{L}$. The observed yield can be compared to other clear water systems as reported by Fujitake et al. (2009), Tsuda et al. (2010) and Kida et al. (2015).

\section{Elemental analysis}

Table 2 reveals the elemental composition of Lake Mansar fulvic acid. On comparison of elemental composition of isolated fulvic acid fraction with other aquatic sources, we observed slightly higher percentage of $\mathrm{C}, \mathrm{H}$ and $\mathrm{N}$ than other freshwater lake fulvic acid (Rice and MacCarthy 1991) as shown in Table 3. However, the present results were comparable to other clear water bodies, viz. Lake Fryxell, Lake Hoare, Ogeechee stream (McKnight et al. 1991) and Lake Biwa (Fujitake et al. 2009).

High nitrogen content in aquatic fulvic acid observed during the present study may be attributed to the presence of higher amount of non-humified polypeptides produced by incomplete hydrolysis of proteinaceous constituents (Ahamadou et al. 2013), and the formation of these compounds with less influence of lignin components derived from terrestrial plants (McKnight et al.1991; Mao et al. 2007; Fujitake et al. 2009).

The $\mathrm{C} / \mathrm{N}$ ratio is considered as the indicator of source of humic substances and its range between 2.0 and 10 suggests origin from unaltered algal matter and non-vascular aquatic plants, whereas higher value suggests origin from vascular land plants (Belzile et al. 1997; Rosa et al. 2005; Mengchang et al. 2008). Hence, the observed range of $\mathrm{C} / \mathrm{N}$ ratio possibly suggests the origin of fulvic acid in presently studied lake is from non-vascular aquatic plants.

Table 3 Comparison of elemental composition of extracted fulvic acid with reported values

\begin{tabular}{llc}
\hline$\%$ & \multicolumn{2}{c}{ Aquatic fulvic acid } \\
\cline { 2 - 3 } & Observed & Reported $^{\mathrm{a}}$ \\
\hline $\mathrm{C}$ & 54.6 & 46.7 \\
$\mathrm{H}$ & 5.04 & 4.2 \\
$\mathrm{~N}$ & 4.3 & 2.3 \\
$\mathrm{O}$ & 36.06 & 45.9 \\
\hline
\end{tabular}

${ }^{\mathrm{a}}$ Rice and MacCarthy (1991)
Table 2 Elemental composition (\%) and atomic ratios of isolated fulvic acid fraction

\begin{tabular}{|c|c|c|c|c|c|c|c|c|}
\hline Humic fraction & $\mathrm{C}(\%)$ & $\mathrm{H}(\%)$ & $\mathrm{N}(\%)$ & $\mathrm{O}(\%)$ & $\mathrm{C} / \mathrm{N}$ & $\mathrm{C} / \mathrm{H}$ & $\mathrm{O} / \mathrm{C}$ & $\mathrm{O} / \mathrm{H}$ \\
\hline Aquatic fulvic acid & 53.6 & 5.04 & 6.3 & 35.06 & 8.5 & 10.6 & 0.65 & 6.96 \\
\hline
\end{tabular}


Also, $\mathrm{O} / \mathrm{C}$ ratio is considered as an indicator of carbohydrate and carboxylic acid contents of humic substances and can be used to compare humic substances from different sources. During the present study, it was $0.65 \%$. High O/C ratio observed presently suggested that the humic substances have undergone a low degree of condensation and are more aliphatic in nature with a higher proportion of carbohydrates (Mengchang et al. 2008; Guéguen et al. 2012; da silva et al. 2018).

\section{Proton nuclear magnetic resonance spectroscopy ( $\mathbf{H}^{1}$-NMR)}

The $\mathrm{H}^{1}$-NMR spectrum of aquatic fulvic acid has been depicted in Fig. 2, and the peaks observed are described in Table 4.

The spectrum of the isolated fulvic acid from water of lake Mansar revealed absorbance in the five regions that are characteristic of humic substances as shown in Table 5 (Kawahigashi et al.1996; Fujitake et al. 2009) however, there were differences in the intensity and location of peaks.

The presence of peak at $0.76 \mathrm{ppm}$ corresponded to absorbance due to protons attached to aliphatic groups. These signals are common in the $\mathrm{H}^{1}$-NMR spectra of fulvic acids isolated from aquatic environments (Thorn et al. 1989; Fujitake et al. 2009). The peaks at 1.19 and $1.41 \mathrm{ppm}$
Table $4 \mathrm{H}^{1}$-NMR peak description of aquatic fulvic acid of Lake Mansar

\begin{tabular}{ll}
\hline Wavelength $(\mathrm{ppm})$ & Peaks observed (ppm) \\
\hline $0-0.9$ & 0.76 \\
$0.9-1.6$ & $1.19,1.41$ \\
$1.6-3.0$ & $1.77,2.06,2.13,2.3$ \\
$3.0-4.3$ & $3.22,4.03,4.21$ \\
$6.0-9.0$ & 8.36 \\
\hline
\end{tabular}

confirm the presence of protons attached to methylene groups in olefins. Signals in the next region, 1.77, 2.06, 2.13 and $2.3 \mathrm{ppm}$ may be attributed to the presence of protons attached to $\mathrm{C}$ atom in carbonyl groups, ester groups and olefins.

This was followed by peaks at $3.22 \mathrm{ppm}$ confirming the presence of methoxy groups and polysaccharides. The next region corresponding to absorbance due to protons of aromatic groups revealed the presence of peaks at $8.36 \mathrm{ppm}$.

Hence, the absorbance at $0.76,1.19,1.41,1.77,2.06$, $2.13,2.3,3.22$ and $8.36 \mathrm{ppm}$ corresponded to the presence of protons attached to groups like aliphatic, olefinic, carbonyl, ester, methoxy, polysaccharides, and aromatic groups.

A careful observation of the location of peaks in the spectrum revealed. This inferred the presence of most of

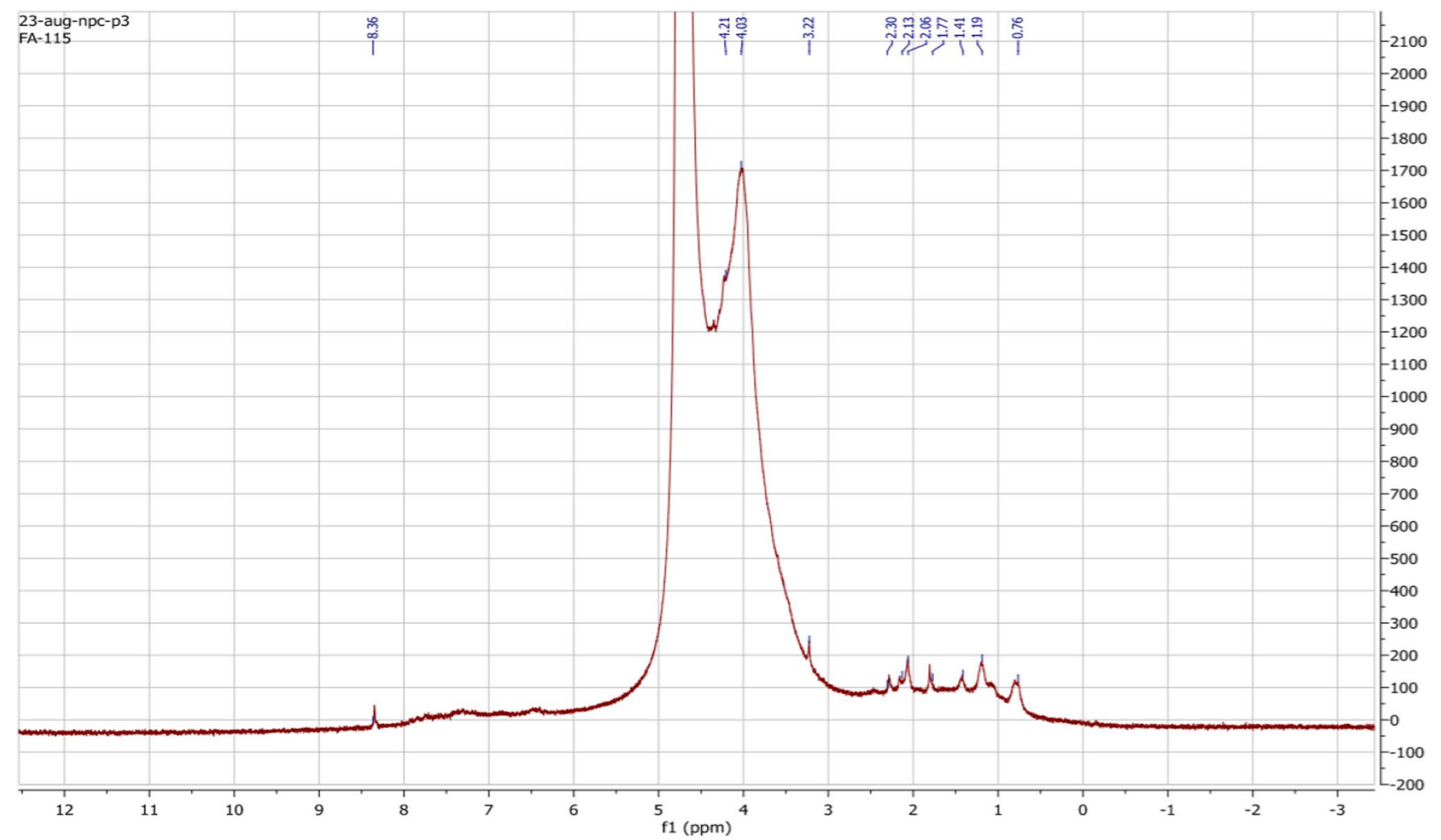

Fig. $2 \mathrm{H}^{1}$-NMR spectrum of aquatic fulvic acid of Lake Mansar 
Table $5 \mathrm{H}^{1}$-NMR peak assignments of humic substances

\begin{tabular}{ll}
\hline Wavelength $(\mathrm{ppm})$ & Functional groups \\
\hline $0-0.9$ & Protons on the terminal methyl groups attached to saturated aliphatic protons \\
$0.9-1.6$ & Protons on methylene $\beta$ attached to olefins \\
$1.6-3.0$ & Protons on methyl and methylene $\alpha$ attached to carbonyl groups, ester groups, and olefins \\
$3.0-4.3$ & Protons on the carbon attached to oxygen-sugars, olefins, and methoxyl groups \\
$6.0-9.0$ & Protons attached to the carbon of heteroaromatic and aromatic rings and to the carbonyl \\
& groups bonded to electronegative groups \\
\hline
\end{tabular}

Kawahigashi et al. (1996), Fujitake et al. (2009)

the peaks in the region $0-4 \mathrm{ppm}$, and only one peak of low intensity in the region 6-9 ppm depicts the predominance of aliphatic groups over aromatic groups in the structure of the isolated fraction. The present finding is in conformity to Wilson (1981), Stuermer and Payne (1976), Ruggiero et al. (1979), Hatcher et al. (1981), Tegelaar et al. (1989), Kim et al. (2006), Baglieri et al. (2012) and Santos et al. (2012) according to whom aliphatic groups are the main constituents of aquatic humic substances.

Hence, based on the results of $\mathrm{H}^{1}$-NMR spectroscopy, it can be concluded that the isolated fulvic acid from the water of Lake Mansar is characterised by peaks of low intensity which mostly correspond to presence of varied functional groups, viz. aliphatic, olefinic, carboxyl, carbonyl, polysaccharides and ester with less abundance of aromatic groups.

\section{Fourier transform infra-red spectroscopy (FTIR)}

The FTIR spectrum of fulvic acid isolated from the water sample of Lake Mansar as depicted in Fig. 3 revealed the presence of peaks at various wavelengths confirming the presence of functional groups as discussed ahead.

The spectrum depicted a broad band at $3401 \mathrm{~cm}^{-1}$ that could be ascribed to the presence of bonded and non-bonded hydroxyl groups (Solomon et al. 2007; Mecozzi et al. 2009; Ahamadou et al. 2013). Another peak was reported at $2468.12 \mathrm{~cm}^{-1}$ that corresponded to presence of aliphatic groups (Stevenson 1994; Šìre 2010).

A broad band observed at $1648.02 \mathrm{~cm}^{-1}$ may be ascribed to the presence of amide groups, quinones and ketones (Stevenson 1994) and another band at $1446.50 \mathrm{~cm}^{-1}$ indicated the presence of aliphatic $\mathrm{C}-\mathrm{H}$ that usually falls in the region $1450-1460 \mathrm{~cm}^{-1}$ (Stevenson 1994).

Absorbance recorded at $1194.26 \mathrm{~cm}^{-1}$ may be because of the presence of cellulose residues as suggested by Enev et al. (2014). This was followed by another peak at $1019.94 \mathrm{~cm}^{-1}$ that may be due to the -OH bending deformation of carboxyl groups confirming the presence of carboxylic groups.

The spectra also revealed the presence of a large number of sharp peaks at absorbance below $1000 \mathrm{~cm}^{-1}$ that revealed the presence of carbohydrates.

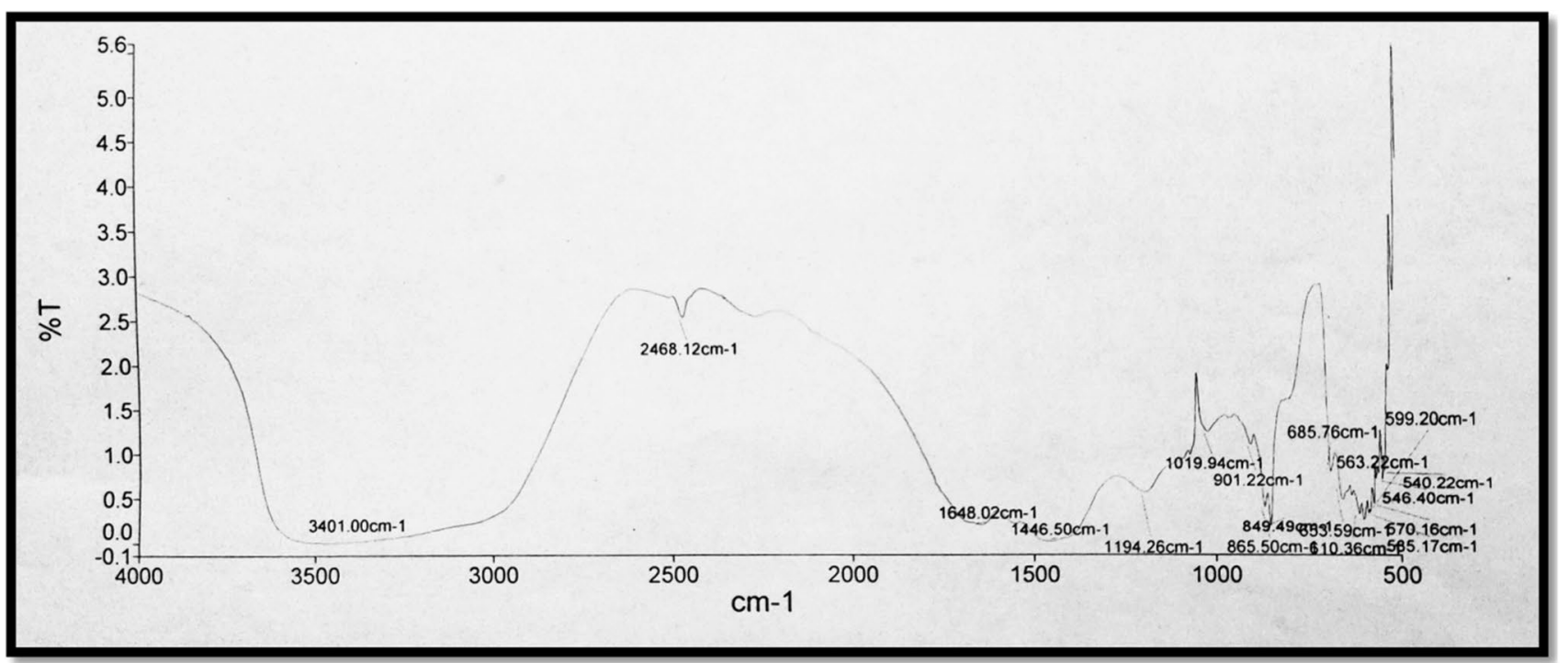

Fig. 3 FTIR Spectrum of aquatic fulvic acid 
Hence, FTIR spectrum of fulvic acid from the water sample of Lake Mansar with absorbances recorded at 3401, 2468.12, 1648.02, 1446.50, 1194.26, 1019.94 and $901.22 \mathrm{~cm}^{-1}$ that confirmed the presence of various functional groups, viz. hydroxyl, aliphatic, amide, quinones, ketones, carboxyl, cellulose and other carbohydrates.

\section{Conclusion}

The present research work was a maiden attempt to isolate and chemically characterise fulvic acid from clear water of Lake Mansar. The yield of isolated fractions was found comparable to other clear water systems; however, it was very less when compared to coloured aquatic systems with high DOC. Based on the present study, a clear picture about the composition and structure of fulvic acid of Lake Mansar was drawn. Characterisation of humic substances using various techniques, viz. element composition, $\mathrm{H}^{1}$-NMR and FTIR, revealed the compound to be more aliphatic than aromatic with the presence of various functional groups, and the conclusion was drawn that the humic material in Lake Mansar is freshly deposited and its major source is from algae and nonvascular plants. The results will add to the data of aquatic humic substances from clear water ecosystems. Moreover, Lake Mansar is one of the oldest lakes in India that also finds mention in Indian mythology and considered to be about ten to fifteen thousand years old (Krishnan and Prasad, 1970; Rai et al. 1997). Being a pioneer study of humic substances from Himalayan region that is known for its unique and rich flora and fauna, this research will be a foundation for similar future studies in this region. Considering the fact that the present study was confined to the littoral zone of the lake, future studies can be conducted to characterise humic substances from deeper layers of lake to understand their effect on biota.

Acknowledgements The authors are thankful to the Department of Zoology, University of Jammu.

Funding The research was not funded by any organisation.

Availability of data and material Data collected by the author and secondary data are cited.

\section{Declarations}

Conflict of interest No conflicts of interest involved.

Ethics approval In compliance with ethical standards.

Consent to participate Consent by both the authors.

Consent for publication Consent by both the authors.
Open Access This article is licensed under a Creative Commons Attribution 4.0 International License, which permits use, sharing, adaptation, distribution and reproduction in any medium or format, as long as you give appropriate credit to the original author(s) and the source, provide a link to the Creative Commons licence, and indicate if changes were made. The images or other third party material in this article are included in the article's Creative Commons licence, unless indicated otherwise in a credit line to the material. If material is not included in the article's Creative Commons licence and your intended use is not permitted by statutory regulation or exceeds the permitted use, you will need to obtain permission directly from the copyright holder. To view a copy of this licence, visit http://creativecommons.org/licenses/by/4.0/.

\section{References}

Adoni AD (1985) Workbook on limnology. Pratibha Publishers C-10 Gour Nagar Sagar, India

Ahamadou B, Huang Q, Yaping L, Iqbal J (2013) Composition and structure of humic substances in long-term fertilization experimental soils of southern China. J Soil Sci Environ Manag 4(4):77-86

Aiken GR, McKnight DM, Wershaw RL, MacCarthy P (1985) An introduction to humic substances in soil, sediment, and water. In: Aiken GR, McKnight DM, Wershaw RL, MacCarthy P (eds) Humic substances in soil, sediment, and water: geochemistry, isolation and characterization. Wiley, New York, pp 1-9

APHA (1985) Standard methods for the examination of water and waste water. American Public Health Association, American Water Works Association and Water Pollution Control Federation, Washington, D. C., 1198

Baglieri A, Gennari M, Ioppolo A, Leinweber P, Negre M (2012) Comparison between the humic acids characteristics of two andisols of different age by: FT-IR and 1 H-NMR spectroscopy and py-FIMS. Geochem Int 50(2):148-158

Banerjee SK, Chakraborty A, Gupta SK (1979) Characterisation of humic and fulvic acid components of some city wastes by Chemical Electrometric and Optical studies. Indian Soc Soil Sci 27:3

Beckett R, Jue Z, Giddings JC (1987) Determination of molecular weight distributions of fulvic and humic acids using flow fieldflow fractionation. Environ Sci Technol 21(3):289-295

Belzile N, Joly HA, Li H (1997) Characterization of humic substances extracted from Canadian lake sediments. Can J Chem 75(1):14-27

Boggs Jr S, Livermore D, Seitz MG (1985) Humic substances in natural waters and their complexation with trace metals and radionuclides: a review. (No. ANL-84-78). Argonne National Lab., IL (USA)

da Silva RR, Lucena GN, Machado ÂF, de Freitas GA, Matos AT, Abrahão WAP (2018) Spectroscopic and elementary characterization of humic substances in organic substrates. Comunicata Scientiae 9(2):264-274

Enev V, Pospíšilová L, Klučáková M, Liptaj T, Doskočil L (2014) Spectral characterization of selected humic substances. Soil Water Res 9(1):9-17

Fujitake N, Kodama H, Nagao S, Tsuda K, Yonebayashi K (2009) Chemical properties of aquatic fulvic acids isolated from Lake Biwa, a clear water system in Japan. Humic Subst Res 5(6):45-53

Ghosal S, Lal J, Singh SK (1991) The core structure of Shilajit humus. Soil Biol Biochem 23(7):673-680

Guéguen C, Burns DC, McDonald A, Ring B (2012) Structural and optical characterization of dissolved organic matter from the lower Athabasca River, Canada. Chemosphere 87(8):932-937

Gul S (2004) Geo ecology of lake Mansar. M.Sc. Dissertation, University of Jammu, Jammu

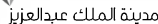

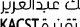
Springer 
Hatcher PG, Maciel GE, Dennis LW (1981) Aliphatic structure of humic acids; a clue to their origin. Org Geochem 3(1-2):43-48

Hertkorn N, Claus H, Schmitt-Kopplin PH, Perdue EM, Filip Z (2002) Utilization and transformation of aquatic humic substances by autochthonous microorganisms. Environ Sci Technol 36(20):4334-4345

IHSS (1985) International Humic Substance Society

Kar S, Maity JP, Jean JS, Lee YC, Nath B, Bundschuh J, Chen CY, Li Z (2011) Role of organic matter and humic substances in the binding and mobility of arsenic in a Gangetic Aquifer. J Environ Sci Health 46(11):1231-1238

Kawahigashi M, Fujitake N, Takahashi T (1996) Structural information obtained from spectral analysis (UV-VIS, IR, $1 \mathrm{H}$ NMR) of particle size fractions in two humic acids. Soil Sci Plant Nutr 4:355-360

Kida M, Maki K, Takata A, Kato T, Tsuda K, Hayakawa K, Hayakawa K, Fujitake N (2015) Quantitative monitoring of aquatic humic substances in Lake Biwa, Japan, using the DAX-8 batch method based on carbon concentrations. Org Geochem 83:153-157

Kim HC, Yu MJ, Han I (2006) Multi-method study of the characteristic chemical nature of aquatic humic substances isolated from the Han River, Korea. Appl Geochem 21(7):1226-1239

Krishnan PV, Prasad R (1970) Tectonic framework of a tertiary belt of the Sub-Himalayas of Jammu. Publication Centre Advance studies Geology, Chandigarh, No, pp 7-19

Lamar RT, Olk DC, Mayhew L, Bloom PR (2014) A new standardized method for quantification of humic and fulvic acids in humic ores and commercial products. J AOAC Int 97(3):721-730

Manskaya SM, Drozdova TV (1968) Geochemistry of organic substances. Pergamon Press, New York, p 347

Mao J, Fang X, Schmidt-Rohr K, Carmo AM, Hundal LS, Thompson ML (2007) Molecular-scale heterogeneity of humic acid in particle-size fractions of two Iowa soils. Geoderma 140(1-2):17-29

McKnight DM, Aiken GR (1998) Sources and age of aquatic humus. In: Hessen DO, Tranvik LJ (eds) Aquatic humic substances: ecology and biogeochemistry. Springer, Berlin, pp 9-37

McKnight DM, Aiken GR, Smith RL (1991) Aquatic fulvic acids in microbially based ecosystems: results from two desert lakes in Antarctica. Limnol Oceanogr 36(5):998-1006

Mecozzi M, Pietrantonio E, Pietroletti M (2009) The roles of carbohydrates, proteins and lipids in the process of aggregation of natural marine organic matter investigated by means of $2 \mathrm{D}$ correlation spectroscopy applied to infrared spectra. Spectrochim Acta Part A Mol Biomol Spectrosc 71(5): 1877-1884

Mengchang HE, Yehong SHI, Chunye LIN (2008) Characterization of humic acids extracted from the sediments of the various rivers and lakes in China. J Environ Sci 20(11):1294-1299

Mukhopadhyay D, Sanyal SK (2004) Complexation and release isotherm of Arsenic in arsenic-humic/fulvic equilibrium study. Soil Res 42(7):815-824

Muscolo A, Sidari M, Attina E, Francioso O, Tugnoli V, Nardi S (2007) Biological activity of humic substances is related to their chemical structure. Soil Sci Soc Am J 71:75-85

NIH (1997) Water quality study of Mansar Lake, in district Udhampur, J\&K. Tech. Rep. No., CS (AR)- 32/96-97: 1-40.

Pandey AK, Pandey SD, Misra V, Vishwanathan PN (1999) Formation of soluble complexes of metals with humia acids and its environmental significance. Chem Ecol 16(4):269-282

Paul VI, Jayakumar P (2010) A comparative analytical study of the cadmium and humic acid contents of two lentic water bodies in Tamil Nadu, India. Iran J Environ Health Sci Eng 7(2):137-144

Rai SP, Singh O, Kumar V (1997) CS (AR)-20/97-98: Water quality monitoring and evaluation of Mansar lake, Dist. Udhampur, J\&K. National Institute of Hydrology

Rice JA, MacCarthy P (1991) Statistical evaluation of the elemental composition of humic substances. Org Geochem 17:635-648
Robards K, McKelvie ID, Benson RL, Worsfold PJ, Blundell NJ, Casey H (1994) Determination of carbon, phosphorus, nitrogen and silicon species in waters. Anal Chim Acta 287(3):147-190

Rodríguez FJ, Núñez LA (2011) Characterization of aquatic humic substances. Water Environ J 25(2):163-170

Rosa AH, Simões ML, de Oliveira LC, Rocha JC, Neto LM, Milori DM (2005) Multimethod study of the degree of humification of humic substances extracted from different tropical soil profiles in Brazil's Amazonian region. Geoderma 127(1-2):1-10

Ruggiero P, Interesse FS, Sciacovelli O (1979) [1H] and [13C] NMR studies on the importance of aromatic structures in fulvic and humic acids. Geochim Cosmochim Acta 43(11):1771-1775

Santos PS, Santos EB, Duarte AC (2012) First spectroscopic study on the structural features of dissolved organic matter isolated from rainwater in different seasons. Sci Total Environ 426:172-179

Šīre J (2010) Composition and properties of rised bog peat humic acids. Doctoral thesis, Riga, University of Latvia

Solomon D, Lehmann J, Thies J, Schäfer T, Liang B, Kinyangi J, Neves E, Petersen J, Luizão F, Skjemstad J (2007) Molecular signature and sources of biochemical recalcitrance of organic C in Amazonian Dark Earths. Geochim Cosmochim Acta 71(9):2285-2298

Srivastava PC, Martin D, Ghosh D, Zech W (1998) Characteristics of humic substances in cultivated and natural forest soils in Sikkim. Geoderma 84(4):345-362

Stevenson FJ (1994) Humus chemistry: genesis, composition, reactions, 2nd edn. John Wiley and Sons Ltd., New York

Stuermer DH, Payne JR (1976) Investigation of seawater and terrestrial humic substances with carbon-13 and proton nuclear magnetic resonance. Geochim Cosmochim Acta 40(9):1109-1114

Szalay A (1964) Cation exchange properties of humic acids and their importance in the geochemical enrichment of $\mathrm{UO} 2++$ and other cations. Geochim Cosmochim Acta 28(10-11):1605-1614

Tegelaar EW, De Leeuw JW, Sáiz-Jiménez C (1989) Possible origin of aliphatic moieties in humic substances. Sci Total Environ 81:1-17

Thorn KA, Folan DW and MacCarthy P (1989) Characterization of the International Humic Substances Society standard and reference fulvic and humic acids by solution state carbon-13 (13C) and hydrogen-1 $(1 \mathrm{H})$ nuclear magnetic resonance spectrometry. In Water Investigation Report 89-4196, US Geological Survey, Denver: 1-93

Thurman EM (1985) Aquatic humic substances. Organic geochemistry of natural waters. Springer, Dordrecht, pp 273-361

Tsuda K, Mori H, Asakawa D, Yanagi Y, Kodama H, Nagao S, Yonebayashi K, Fujitake N (2010) Characterization and grouping of aquatic fulvic acids isolated from clear-water rivers and lakes in Japan. Water Res 44(13):3837-3846

Varadachari C, Chattopadhyay T, Ghosh K (1997) Complexation of humic substances with oxides of iron and aluminium. Soil Sci 162(1):28-34

Wershaw RL (1985) Application of nuclear magnetic resonance spectroscopy for determining functionality in humic substances. In: Aiken GR, McKnight DM, Wershaw RL, MacCarthy P (eds) Humic substances in soil, sediment, and water: geochemistry. isolation and characterization, Wiley, New York, pp 561-582

Wilson MA (1981) Applications of nuclear magnetic resonance spectroscopy to the study of the structure of soil organic matter. J Soil Sci 32(2):167-186

Publisher's Note Springer Nature remains neutral with regard to jurisdictional claims in published maps and institutional affiliations. 